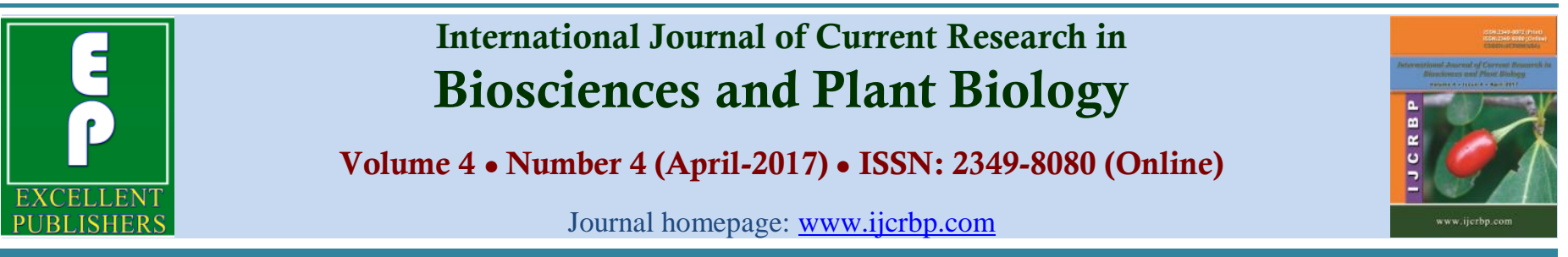

\title{
Studies on Genetic Diversity for Yield, Growth and Quality Traits in Sweet Potato [Ipomoea batatas (L.) Lam.]
}

\author{
Devesh Pratap Singh, Chandra Deo ${ }^{1}$, Deepak Kumar Gautam², Rajesh Kumar ${ }^{3}$ and \\ Pushpendra Kumar ${ }^{2}$
}

\author{
${ }^{1}$ Assistant Professor and ${ }^{2}$ Research Scholar, Department of Vegetable Science, Narendra Deva University of Agriculture \& \\ Technology, Kumarganj, Faizabad-224 229 (U.P.), India \\ ${ }^{3}$ Research Scholar Department of Horticulture, Narendra Deva University of Agriculture \& Technology, Kumarganj, Faizabad- \\ 224229 (U.P.), India
}

\section{*Corresponding author.}

\begin{abstract}
The experiment was conducted at main Experimental Station of Department of Vegetable Science, Narendra Deva University of Agriculture and Technology, Narendra Nagar, Kumarganj, Faizabad. During October 2013 to February 2014, to assess variability, heritability and genetic advance for quantitative characters, estimate correlation coefficients among the important economic traits and to find out the direct and indirect effect of yield components, yield by path coefficient analysis and genetic divergence. Experiment at material for the study consisted of 33 genotypes including two checks (NDSP-10, NDSP-65). The experiment was conducted in Randomized Block Design with three replications. Observations were recorded on thirteen quantitative characters. A total of 33 genotypes was grouped in to 5 clusters. The highest numbers of entries were present in cluster I which contained 20 genotypes followed by cluster II which carried 10 genotypes. Other clusters such as III, IV and V recorded minimum contained one genotype each in cluster. The maximum intra-cluster distance was recorded for cluster II (95.07) followed by cluster I (53.91), cluster III, No intra-cluster distance was recorded IV and V since the value was recorded zero in these cluster. The maximum inter cluster distance was found by cluster I with V (353.16) which suggested that member of these genotypes are genetically very diverse to each other. The minimum inter-cluster distance was observed between clusters I with II (99.45). Highest per cent contribution towards total genetic divergence was exhibited by length of vine $(26.33 \%)$, followed by branches per vine (19.89\%), internodal length $(17.61 \%)$ average weight of tuber $(10.80)$, width of leaves $(9.47 \%)$, leaves per vine (5.87), length of leaves $(5.68 \%)$, girth of tuber $(1.89 \%)$, yield per hectare $(0.95 \%)$, yield per plant $(0.57 \%)$, tuber per vine and days to bud initiation is not having any contribution. Thus, there exists ample variation and as a result scope of improvement after selection in the available germplasm of sweet potato.
\end{abstract}

\section{Article Info}

Accepted: 28 March 2017

Available Online: 06 April 2017

\section{Keywords}

Genetic divergence Ipomoea batatas (L) Lam. Mahalanobis $\mathrm{D}^{2}$ analysis Sweet potato 


\section{Introduction}

Mahalanobis $\mathrm{D}^{2}$ multivariate analysis is a valuable tool for obtaining quantitative estimate of divergence between biological populations. In the process of formulating the sweet potato crop improvement programmes, understanding about the nature and degree of genetic divergence available in the germplasm plays pivotal role. Genetic divergence existing in the population helps in selecting suitable parents for hybridization programme. Therefore, the present investigation was carried out to examine the nature and magnitude of genetic divergence in 33 genotypes of sweet potato having different geographical origins.

\section{Materials and methods}

The experimental material for the present investigation comprised thirty eight sweet potato genotypes of diverse collected from different places in India and being maintained at main experiment station in the Department of Vegetable Science, N.D. University of Agriculture and Technology, Narendra Nagar (Kumarganj), Faizabad (U.P.). The experiment was conducted in Randomized Complete Block Design with three replications during Rabi season in 2012-13 to assess the performance of 33 genotypes.

Planting in nursery was done 3 months ahead of planting in main field. The selected tubers were planted $5-10 \mathrm{~cm}$ deep at a spacing of $20 \mathrm{~cm}$ in rows, $60 \mathrm{~cm}$ apart. The sprouts were cut often about 40-45 days and planted in secondary planted nursery for further growth. The cutting, $20-30 \mathrm{~cm}$ in length was planted in this nursery at a distance of $60 \mathrm{~cm}$ between rows and $20 \mathrm{~cm}$ in plant to plant. All the recommended agronomic package of practices and plant protection measures were followed to raise a good crop.

Observations were recorded on thirteen quantitative characters viz., days to initiation of bud, length of leaves $(\mathrm{cm})$, width of leaves $(\mathrm{cm})$, length of vine $(\mathrm{cm})$, number of branches per plant, number of leaves per vine, internodal length $(\mathrm{cm})$, length of tubers $(\mathrm{cm})$, girth of tubers $(\mathrm{cm})$, number of tubers per vine, average weight of tuber $(\mathrm{g})$, yield per plant $(\mathrm{g})$, tuber yield $(\mathrm{Q} / \mathrm{ha})$. The genetic divergence was estimated using $\mathrm{D}^{2}$ statistics of Mahalanobis (1936) and the population were grouped into clusters by following the methods suggested by Tocher (Rao, 1952).

\section{Results and discussion}

The results of $\mathrm{D}^{2}$ analysis are presented in Tables $1,2,3$ and 4. The concept of $\mathrm{D}^{2}$ introduced by Mahalanobis (1936) is neither restricted to population nor to the previously known population and the pattern obtained by $\mathrm{D}^{2}$ analyses substantially change with the addition of more characters. The technique is based on self-weighing on genetic variability (Rao, 1952). Obviously among several techniques, Mahalanobis generalized distance has occupied a unique place in the plant breeding.

Using $\mathrm{D}^{2}$ statistics, the 33 germplasm of sweet potato were grouped into five distinct non-overlapping clusters (Table 1). This indicated considerable diversity among the germplasm collection evaluated in the present study. Cluster I had 20 out of 33 entries which were characterized by highest cluster means for followed by Cluster II (10) cluster III (1) and cluster IV (1) genotypes cluster V (1) genotypes each (Bhadauria et al., 2013; Rabbani et al., 2012; Quamruzzaman and Ahmad, 2012).

The five clusters in aforesaid genetic divergence analysis contained frequently the genotypes of heterogeneous origin Although the genotypes originated in the same place or geographic region were also found to be grouped together in same cluster, the instance of grouping of genotypes of different origin or geographic region in the same cluster were observed in case of all the five clusters. This is suggests that lack of parallelism between genetic and geographic diversity. Therefore, the selection of parental materials for hybridization programme, simply based on geographic diversity may not be a successful exercise. The choice of suitable diverse parents based on genetic divergence analysis would be more rewarding, than the choice on basis of geographic diversity. This finding is in agreement with the reports advocating lack of definite relationship between genetic and geographic diversity in sweet potato.

The maximum intra-cluster distance was recorded for cluster II (95.07) and minimum intra-cluster distance was recorded I (53.91) and no intra-cluster distance was recorded in the cluster III, IV and V. The maximum inter cluster distance was found by cluster I with V (353.16) followed by cluster III with IV (341.73), cluster IV with $\mathrm{V}$ (338.62). The minimum inter-cluster distance was observed between clusters I with II (99.45) followed by cluster I with IV (134.88) (Table 2). This indicated that these groups were less divergence. These results are supported by Teshome et al. (2003). 
Table 1. Clustering pattern of 33 genotypes of sweet potato on the basis of Mahalanobis $\mathrm{D}^{2}$ statistics.

\begin{tabular}{|c|c|c|}
\hline $\begin{array}{l}\text { Cluster } \\
\text { number }\end{array}$ & $\begin{array}{l}\text { No. of } \\
\text { genotypes }\end{array}$ & Genotypes \\
\hline I & 20 & $\begin{array}{l}\text { IGSP-10, NDSP-24, NDSP-10, NDSP-23, NDSP-22, NDSP-3, NDSP-6, RNSP, NDSP-5, NDSP-16, NDSP-18, NDSP-13, NDSP-7, } \\
\text { NDSP-19, NDSP-17, NDSP-4, X-29, NDSP-8, NDSP-11, NDSP-20 }\end{array}$ \\
\hline II & 10 & NDSP-9, NDSP-15, NDSP-1, NDSP-27, NDSP26, NDSP-65, NDSP-14, NDSP-25, NDSP-21, NDSP-2 \\
\hline III & 1 & NDSP-12 \\
\hline IV & 1 & IGSP-4 \\
\hline $\mathbf{V}$ & 1 & IGSP-12 \\
\hline
\end{tabular}

Table 2. Intra and inter clusters $\mathrm{D}^{2}$ values for five clusters in sweet potato.

\begin{tabular}{|c|c|c|c|c|c|}
\hline Cluster number & $\mathbf{I}$ & II & III & IV & $\mathbf{V}$ \\
\hline I & 53.91 & 99.45 & 205.76 & 134.88 & 353.16 \\
\hline II & & 95.07 & 207.25 & 178.13 & 330.76 \\
\hline III & & & 0.00 & 341.73 & 143.07 \\
\hline IV & & & & 0.00 & 338.62 \\
\hline $\mathbf{V}$ & & & & & 0.00 \\
\hline
\end{tabular}

Table 3. Cluster mean for 13 characters in sweet potato.

\begin{tabular}{|c|c|c|c|c|c|c|c|c|c|c|c|c|c|}
\hline $\begin{array}{l}\text { Characters } \\
\text { Cluster } \\
\text { No. }\end{array}$ & $\begin{array}{l}\text { Days to } \\
\text { bud } \\
\text { initiation }\end{array}$ & $\begin{array}{l}\text { Length } \\
\text { of leaf } \\
(\mathrm{cm})\end{array}$ & $\begin{array}{l}\text { Width } \\
\text { of leaf } \\
(\mathrm{cm})\end{array}$ & $\begin{array}{l}\text { Length of } \\
\text { vine } \\
\text { (cm) }\end{array}$ & $\begin{array}{l}\text { Branches/ } \\
\text { Vine }\end{array}$ & $\begin{array}{l}\text { Leaves/ } \\
\text { Vine }\end{array}$ & $\begin{array}{l}\text { Inter- } \\
\text { nodal } \\
\text { length } \\
(\mathrm{cm})\end{array}$ & $\begin{array}{l}\text { Length } \\
\text { of tuber } \\
(\mathrm{cm})\end{array}$ & $\begin{array}{l}\text { Girth } \\
\text { of tuber } \\
(\mathrm{cm})\end{array}$ & $\begin{array}{l}\text { Tubers/ } \\
\text { Vine }\end{array}$ & $\begin{array}{l}\text { Average } \\
\text { weight of } \\
\text { tuber (g) }\end{array}$ & $\begin{array}{l}\text { Yield/ } \\
\text { plant (g) }\end{array}$ & $\begin{array}{l}\text { Yield/ } \\
\text { hectare } \\
\text { (q) }\end{array}$ \\
\hline Cluster-I & 8.69 & 5.92 & 5.86 & 61.93 & 5.31 & 111.69 & 3.10 & 15.64 & 14.27 & 3.52 & 81.84 & 281.33 & 235.92 \\
\hline Cluster-II & 8.86 & 6.25 & 5.28 & 76.32 & 7.72 & 171.51 & 3.48 & 15.84 & 14.84 & 3.41 & 83.10 & 274.23 & 226.44 \\
\hline Cluster-III & 8.22 & 5.37 & 5.71 & 153.03 & 5.14 & 314.49 & 2.52 & 14.30 & 10.91 & 4.07 & 72.53 & 326.36 & 271.97 \\
\hline Cluster-IV & 7.80 & 7.43 & 7.37 & 53.80 & 5.77 & 90.82 & 3.43 & 15.43 & 21.43 & 2.30 & 172.70 & 409.10 & 331.44 \\
\hline Cluster-V & 9.23 & 5.73 & 5.57 & 175.33 & 3.83 & 102.33 & 6.58 & 18.60 & 18.73 & 2.80 & 143.18 & 387.17 & 322.63 \\
\hline
\end{tabular}


An examination on the estimates of within and between clusters of genetic diversity revealed that the genotypes of same cluster had little genetic divergence from each other with respect to aggregate effect of 13 characters studied (Table 3). Therefore, the chances of obtaining good segregates by crossing the members of the same cluster are very low. It would be logical to attempt crosses between the genotypes belonging to clusters separated by large inter-cluster distances. In this context, the highest intra-cluster distance was recorded between cluster II (95.07) and I (53.91) followed by cluster III, IV and cluster V (Islam et al., 2010; Kabir et al., 2009; Sundaram and Vadivel, 2007).

A perusal showed that cluster-4 mean for different traits indicate considerable different between the clusters. All clusters form $\mathrm{I}$ and $\mathrm{V}$ had in general medium mean performance for most of the characters exhibiting extreme cluster means. Maximum cluster mean for tuber yield per hectare was observed in cluster IV followed by cluster V and III when the lowest was observed in cluster II. Similar result was also preponderance by Rao et al. (1994) and Teshome et al. (2003).

Highest per cent contribution towards total genetic divergence (Table 4) was exhibited by length of vine (26.33\%), followed by branches per vine (19.89\%), internodal length $(17.61 \%)$ average weight of tuber (10.80), width of leave (9.47\%), leave per vine (5.87), length of leave $(5.68 \%)$, girth of tuber $(1.89 \%)$, yield per hectare $(0.95 \%)$, yield per plant $(0.57 \%)$, tuber per vine and days to bud initiation is not having any contribution.

Table 4. Per cent contribution of 13 characters towards total genetic divergence in sweet potato.

\begin{tabular}{|c|c|c|}
\hline Source & Times ranked $1^{\text {st }}$ & Per cent contribution \\
\hline Days to bud initiation & 0.01 & 0.00 \\
\hline Length of leaves $(\mathrm{cm})$ & 30 & 5.68 \\
\hline Width of leaves $(\mathrm{cm})$ & 50 & 9.47 \\
\hline Length of vine $(\mathrm{cm})$ & 139 & 26.33 \\
\hline Branches/Vine & 105 & 19.89 \\
\hline Leaves/Vine & 31 & 5.87 \\
\hline Internodal length $(\mathrm{cm})$ & 93 & 17.61 \\
\hline Length of tuber(cm) & 5 & 0.95 \\
\hline Girth of tuber(cm) & 10 & 1.89 \\
\hline Tubers/Vine & 0.01 & 0.00 \\
\hline Average weight of tuber $(\mathrm{g})$ & 57 & 10.80 \\
\hline Yield/ Plant (g) & 3 & 0.57 \\
\hline Yield/ Hectare (q) & 5 & 0.95 \\
\hline
\end{tabular}

\section{Conflict of interest statement}

Authors declare that they have no conflict of interest.

\section{References}

Bhadauria, P.K., Hussain, M.A., Poti, N.N., 2013. Studies on genetic variability, heritability, genetic advance, correlation coefficient and $\mathrm{D}^{2}$ analysis in sweet potato (Ipomea batatas L.) National Conference on Tuber Crops (other than Potato) or Sustainable Agriculture and Livelihood Security in Changing Scenario, AAU, Jorhat. April 29. pp.50-51.
Islam, M.R., Hossain, M.S., Bhuijan, M.S.R., Hasan, G.N., Syed, A., 2010. Multivariate analysis of bitter gourd. Middle East J. Sci. Res. 5(2), 86-90.

Kabir, M.Y., Khan, A.S., M.M.R., Hassain, M.S., 2009. Genetic divergence in pointed gourd. J. Agric. Rural Develop. 7(1/2), 87-92.

Mahalanobis, P.C., 1936. On the generalized distance in statistics. Proc. Natl. Acad. Sci. India. 12, 49-55.

Quamruzzaman, A.K.M., Ahmad, S., 2012. Genetic analysis of some yield components of bottle gourd [Lagenaria siceraria (Mol.) Standl.]. SAARC J. Agric. 8(1), 1-9.

Rabbani, M.G., Naher, M.J., Hoque, S., 2012. 
Variability, character association and diversity analysis of ridge gourd (Luffa acutangula Roxb.) genotypes of Bangladesh. SAARC J. Agric. 10(2), 1-10.

Rao, C.R., 1952. Advanced Statistical Methods in Biometrieal Research. John Wiley and Sons, Inc., New York. pp.357-363.
Sundaram, V., Vadivel, E., 2007. Genetic divergence in bitter gourd under salt stress. Crop Res. (Hisar) 1/3, 139-142.

Teshome, A., Veeraragavathatham, D., Kannan, M., 2003. Genetic divergence for yield and yield contributing characters in sweet potato. South Ind. Horticult. 51(1/6), 40-45.

\section{How to cite this article:}

Singh, D. P., Deo, C., Gautam, D. K., Kumar, R., Kumar. P., 2017. Studies on genetic diversity for yield, growth and quality traits in sweet potato [Ipomoea batatas (L.) Lam.]. Int. J. Curr. Res. Biosci. Plant Biol. 4(4), 113-117. doi: https://doi.org/10.20546/ijcrbp.2017.404.017 